\title{
Florida Fresh: Cucumbers ${ }^{1}$
}

\author{
Claudia Peñuela ${ }^{2}$
}

\section{Nutrition Facts}

The Florida Cucumber contains:

$\checkmark$ Water. Water maintains your body's hydration, preventing water retention.

$\checkmark$ Vitamin C. Vitamin C helps to heal cuts and

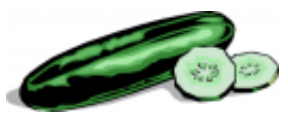
keeps teeth and gums healthy.

$\checkmark$ Minerals such as phosphorus and potassium.

$\checkmark$ No fat, cholesterol or sodium. They are low in calories.

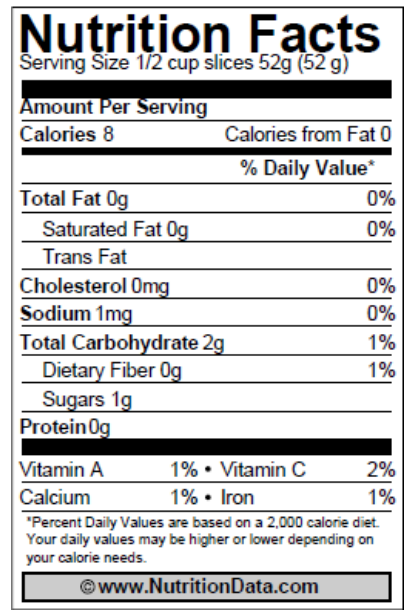

\section{Why Buy Locally?}

The U.S. Department of Agriculture (USDA) estimates that the average farmers' markets produce travels about $\mathbf{5 0}$ miles to its destination, compared to $\mathbf{2 , 0 0 0}$ miles for supermarket produce.

Buy locally and get these benefits:

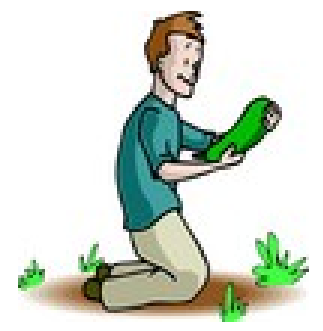

$>$ Freshness and good nutrition. Fruits and vegetables harvested in their peak have better flavor and nutritional characteristics.

$>$ Social/cultural. Helps the community to be aware of the importance of agriculture.

$>$ Environmental. Protects the natural resources such as green space, wildlife, water, air, and soil.

$>$ Economic. Promotes a local labor force.

\section{Where are Florida's cucumbers harvested?}

Most of Florida's cucumbers are grown in West Central and South Florida. Florida farmers produce fresh cucumbers for the market and for processing and pickling.

1. This document is FCS8877, one of a series of the Department of Family, Youth and Community Sciences, Florida Cooperative Extension Service, Institute of Food and Agricultural Sciences, University of Florida. First published: August 2009.Visit the EDIS Web site at http://edis.ifas.ufl.edu.

2. Claudia Peñuela, nutrition assistant-EFNEP, Department of Family, Youth and Community Sciences; Institute of Food and Agricultural Sciences; University of Florida; Gainesville, FL 32611.

The I nstitute of Food a nd Agricultural S ciences ( IFAS) i s a $\mathbf{n}$ E qual Opportunity I nstitution a uthorized to provide $r$ esearch, e ducational information and other services only to individuals and institutions that function with non-discrimination with respect to race, creed, color, religion, age, disability, sex, sexual orientation, marital status, national origin, political opinions or affiliations. U.S. Department of Agriculture, Cooperative Extension Service, University of Florida, IFAS, Florida A. \& M. University C ooperative Extension Program, and B oards of County

Commissioners Cooperating. Millie Ferrer-Chancy, Interim Dean. 


\section{When can you buy Florida cucumbers?}

You can buy Florida cucumbers October through June. This is nine months of the year!

\begin{tabular}{|l|l|l|l|l|l|l|l|l|l|l|l|}
\hline JAN & FEB & MAR & APR & MAY & JUN & JUL & AUG & SEP & OCT & NOV & DEC \\
\hline
\end{tabular}

\section{Select}

$\checkmark$ Cucumbers with a deep green color.

$\checkmark$ Cucumbers that are firm in their entire length, with no soft spots.

$\checkmark$ Cucumbers that are well-shaped and are heavy for their size.

$\checkmark$ Cucumbers that have not dried up at their tips.

\section{Florida Fresh Cucumbers: From Market to Table}

\section{cucumber Yogurt-Dip \\ 2 cups plains low-fat yogurt \\ 2 large cucumbers, peeled, seeded, and grated \\ $1 / 2$ cup nonfat sour cream \\ 1 Tbsp lemon juice \\ 1 Tbsp fresh dill \\ 1 garlic clove, chopped \\ 1 cup cherry tomatoes \\ 1 cup broccoli florets \\ 1 cup baby carrots}

\section{Yield: 6 Servings Time: 15 minutes}

1. Peel, seed, and grate one cucumber. Slice the other cucumber and set aside.

2. Mix yogurt, grated cucumber, sour cream, lemon juice, dill, and garlic in a serving bowl. Chill for 1 hour.

3. Arrange tomatoes, cucumbers, broccoli, and carrots in a colorful platter. Serve with cucumber dip.

* Nutrition info per serving: Calories: 100 cal; Total Fat 2g; Sodium 90 mg; Total Carbohydrate 17g; Fiber 2g; Protein 7g; Vit A 70\%; Vit C 35\%; Calcium 20\%; Iron 4\%

* Vitamin A, Vitamin C, Calcium and Iron listed as \% of daily value based on 2,000 calories.

Adapted from: www.fruitsandveggiesmatter.gov/downloads/explore_recipe_cards.pdf

\section{Florida Cucumber Salad with Balsamic Vinaigrette}

For the dressing
1 Tbsp finely chopped thyme
2 Tbsp balsamic vinegar
2 Tbsp olive oil
2 Tbsp Dijon mustard
1 cucumber with peel, washed and thinly sliced
Cracked black pepper, to taste

\section{Yield: 2 Servings Time: $\mathbf{1 5}$ minutes}

1. In a small saucepan, add the thyme, vinegar and olive oil. Heat over very low heat to blend and intensify the flavors, about 5 minutes.

2. Remove from heat and whisk in the mustard until well blended.

3. In a serving bowl, add the cucumber slices. Pour the dressing over the cucumbers and toss to coat evenly.

4. Add the black pepper to taste. Refrigerate until ready to serve.

Nutrition info per serving: Calories:160 cal; Total Fat $14 \mathrm{~g}$; Sodium $184 \mathrm{mg}$; Total Carbohydrate $8 \mathrm{~g}$; Fiber $1 \mathrm{~g}$; Protein $3 \mathrm{~g}$; Potassium $255 \mathrm{mg}$; Saturated fat $2 \mathrm{~g}$; Calcium $37 \mathrm{mg}$;

Monounsaturated fat $10 \mathrm{~g}$ 